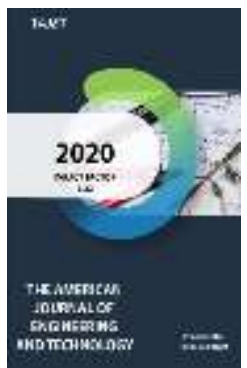

Journal Website: http://usajournalshub.c om/index,php/tajet

Copyright: Original content from this work may be used under the terms of the creative commons attributes 4.0 licence.

\section{The Importance Of The Extension Tool In Reducing The Inequality Of Yarn}

\author{
Sanobar Atoevna Khamraeva \\ Doctor Of Technical Sciences, Professor, Department Of "Textile Fabric Technology", \\ Tashkent Institute Of Textile And Light Industry, Uzbekistan \\ Nodira Bakhtiyarovna Yusupova \\ Assistant,Department Of “Textile Fabric Technology", Tashkent Institute Of Textile And Light \\ Industry, Uzbekistan \\ Dilmukhammad Davronbek Ogli Atambaev \\ Assistant, Department Of “Metrology, Standardization And Quality Management”, \\ Namangan Institute Of Engineering Technology, Uzbekistan \\ Muhriddin Hakimjon Ogli Hasanov \\ Master Student, Metrology, Standardization And Quality Management (Textile And Light \\ Industry), Namangan Institute Of Engineering Technology, Uzbekistan
}

\title{
ABSTRACT
}

In the spinning process, spinning machines have improved the stretching tool, reducing their unevenness by straightening and parallelism of fiber ends, reducing the number of yarn breaks in the production of quality textile and knitted fabrics, a sharp increase in labor productivity, reducing production costs, other economic indicators.

\section{KEYWORDS}

Yarn, roughness, cotton, stretching tool, productivity, product, texture

\section{INTRODUCTION}

In Uzbekistan, special attention is paid to ensuring the rapid development of the textile industry, expanding the production of high quality and competitive finished products, its export to major foreign markets. Uzbekistan is one of the largest producers of natural textile fibers, yam and knitwear in the world. Creation of new high-tech jobs based on ensuring high and stable growth rates in the textile 
and clothing industry of the Republic, attraction and development of foreign direct investment, production and export of competitive products, implementation of strategically important modernization projects, systematic work is being carried out to further deepen the structural reorganization, aimed at technical and technological modernization of enterprises, the introduction of an advanced “cluster model” [1, 2017].

\section{THE MAIN FINDINGS AND RESULTS}

In order to expand the production and export of high quality finished textile products, to promote national brands in world markets, the widespread introduction of advanced innovative technologies, know-how, design developments, localization of modern models of accessories and accessories is of great importance.

Certainly, for the quality of the textile product, it is important that the level of unevenness of the raw textile yarns is reduced.

So as to improve the stretching device on the spinning machine to reduce the unevenness of the yarn, research work was carried out at the Bukhara enterprise "ARK ECO TEXTILE" LLC.

There are direct, indirect methods of estimating fiber correction, but some of them are either too cumbersome or not sufficiently accurate $[2,2018]$.

Direct methods can include the following methods: the method of measuring the length of the fiber before and after the correction, the method of scattering laser radiation, the method of studying the structure of the yarn in an immersion liquid under a microscope or a special OMEST instrument.

Indirect methods include the following methods: the method of estimating the degree of correction on the index of rupture toughness of the plate, or the method of Lendesley-Leonteva on the electrocapillary rise height of the electrolyte solution.

1. The method of estimating fiber straightening by measuring the length of individual fibers before and after correction is very cumbersome, as the average value must be determined in such a number of experiments that the error must be less than $3 \%$ (at least 250 measurements).

2. The method of diffusion of laser radiation (developed at the Moscow Textile Institute). This method determines the coefficient of straightening of the fibers, the proportion of twisted ends, a complex indicator of fiber orientation and straightening, the average angle of fiber orientation [4, pp. 21-30].

3. The method of studying the orientation of the fibers in the yarn in the immersion liquid in the OMEST tool [5, p. 35] is complicated because it is based on the introduction of dyed fibers into the cotton (before the shaving machine).

4. In Len NIITP developed a method of complex assessment of the structure of the pile and the degree of straightening of the fibers in terms of tensile strength and KSL tool. Breaking work depends on many parameters: the elasticity of the fibers, the average number of fibers in the cross section of the fiber, the longitudinal length of the fiber, the number of complexes in the cross section of the fiber, the twist of the fiber, the angle of orientation of the fibers and so on. As the degree of straightening and parallelization of the fibers increases, the amount of contact between them decreases, which leads to a decrease in the relative toughness of the fiber at break [6, p. 12].

The assessment of the degree of flattening and orientation of the fibers in the semi-finished product is based on determining the tensile strength of the pile. 
- To identify their main shortcomings on the basis of research of technologies for the production of individual yams;

- To achieve quality yarn based on the analysis of the results of research;

The stretching devices of spinning machines have undergone drastic changes in recent years. Instead of four-cylinder stretching tools, first high-reef cylindrical stretching tools, then " $3 \times 4$ ", " $4 \times 3$ ", " $3 \times 3$ " curved stretching devices are used. The RSB-D-40 has a spinning speed of $1200 \mathrm{~m} / \mathrm{min}$ and is equipped with a "4×3" stretcher. (3 reef cylinders and 4 elastic rollers).

Previously, the output roller for different lengths of cotton fiber was used in sizes 32,35 and $38 \mathrm{~mm}$ in diameter, while the " $4 \times 3$ " stretching tool is universal and is used effectively for stretching cotton and chemical fibers of different lengths $[3,2018]$.

\section{8 \\ $-8088$ \\ $7 * 4$

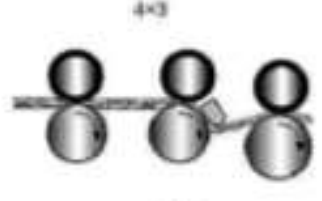 \\ $3 \times 3$ \\ Figure 1. Schematic of stretching tools of spinning machines}

In this study, modifications were made to the cylinders of the stretching tool in the spinning [3, 2018] and RSB-D, taking into account that the roughness eliminated in the spinning process may not be repeated in the spinning to increase the smoothness of the fabric surface by straightening and parallelizing the fiber ends and reducing the product roughness [3, 2018] -40 spinning machines were used as the object of the experiment. The technological parameters of the RSB-D-40 spinning machine installed at the Peshkutex spinning mill are given in Table 1.

Table 1

Technological mode of RSB-D-40 grinding machine

\begin{tabular}{|c|l|c|c|c|}
\hline & & \multirow{2}{*}{$\begin{array}{c}\text { Unit of } \\
\mathrm{t} / \mathrm{r}\end{array}$} & \multicolumn{1}{|c|}{ Name of indicators } & \multicolumn{2}{c|}{ RIETER Company 2 passes } \\
\cline { 4 - 5 } & measurement & basal & Developed \\
\hline 1. & Machine brand & & RSB-D-40 & RSB-D-40 \\
\hline 2. & The thickness of the pile & tex & 5200 & 5300 \\
\hline 3. & Number & $\mathrm{Nm}$ & 0,19 & 0,19 \\
\hline 4. & Number of additions & & 6,0 & 6 \\
\hline 5. & Total elongation & & 1,03 & 6,0 \\
\hline 6. & The custom stretch rear & & 4,97 & 1,03 \\
& cylinder is the front cylinder & & & 4,97 \\
\hline 7. & Cylinder diameter: & $\mathrm{mm}$ & 40 & \\
\hline & First (back) & $\mathrm{mm}$ & 30 & 35 \\
\hline & Second & $\mathrm{mm}$ & 30 & 35 \\
\hline & Third & & & 30 \\
\hline
\end{tabular}




\begin{tabular}{|c|c|c|c|c|}
\hline 8. & Output speed & $\mathrm{m} / \mathrm{min}$ & 560 & 560 \\
\hline 9. & Productivity & $\mathrm{kg} / \mathrm{s}$ & 330 & 330 \\
\hline 10 & Taz diameter & $\mathrm{mm}$ & 600 & 600 \\
\hline 11. & $\begin{array}{l}\text { The length of the wick in the } \\
\text { pelvis }\end{array}$ & $\mathrm{m}$ & 4300 & 4300 \\
\hline 12. & $\begin{array}{l}\text { The weight of the wick in the } \\
\text { pelvis }\end{array}$ & $\mathrm{kg}$ & 22 & 22 \\
\hline 13. & $\begin{array}{l}\text { Load on rollers: } \\
\qquad \begin{array}{l}\text { The third line } \\
\text { The second line } \\
\text { The first line (issuer.) }\end{array}\end{array}$ & $\begin{array}{l}\mathrm{kg} \\
\mathrm{kg} \\
\mathrm{kg}\end{array}$ & $\begin{array}{l}72 \\
72 \\
50\end{array}$ & $\begin{array}{l}76 \\
70 \\
50\end{array}$ \\
\hline 14. & $\begin{array}{l}\text { The distance between the } \\
\text { axes of the cylinders: } \\
\qquad \text { I - II } \\
\text { II - III }\end{array}$ & $\begin{array}{l}\mathrm{mm} \\
\mathrm{mm}\end{array}$ & $\begin{array}{l}45 \\
41\end{array}$ & $\begin{array}{c}45 \\
38,5\end{array}$ \\
\hline 15. & $\begin{array}{c}\text { Template thickness } \\
\text { I - II } \\
\text { III - IV }\end{array}$ & $\begin{array}{l}\mathrm{mm} \\
\mathrm{mm}\end{array}$ & $\begin{array}{c}6 \\
15\end{array}$ & $\begin{array}{c}10 \\
6 \\
\end{array}$ \\
\hline
\end{tabular}

The following formulas are used in the selection of the wire, taking into account the addition of a correction a to the length of the fiber Ішт or the diameters of two adjacent cylinders with a template.

$$
\begin{aligned}
& R=\ell_{\text {шт }}+a \text { ёки } \\
& R=U+\frac{d_{1}+d_{2}}{2} ;
\end{aligned}
$$

from here

$$
U=R-\frac{d_{1}+d_{2}}{2}
$$

where: lшт - staple length of the fiber, mm; a is the correction factor (its magnitude depends on the structure of the stretching tool); Template between Sh-elongation pairs, $\mathrm{mm}$; $\mathrm{d} 1$ and $\mathrm{d} 2$ are the diameters of the first and second cylinders, $\mathrm{mm}$.

In the experiments, the slope of the cylindrical grooves (rifles) was changed to an angle $\mathrm{a}=$ 40 a $a=4^{\circ}, 57^{\prime}$.
The experiments were carried out in the production conditions of the Peshkutex spinning mill.

The influence of fiber orientation on the semifinished product, yarn quality and spinning technological processes on the stretching tool of the spinning machine installed in the enterprise (control version) and the improved stretching tool (experimental version) was studied.

In spinning, the following sorting of the factory was used: cotton fiber "Bukhara 6" type 4 type II-60\% and "Bukhara 8" type 4 type III grade- $40 \%$.

Semi-finished products of each variant and yarn with a linear density of 29.4 and 50 tex were produced on a spinning machine R-40 by RIETER according to the spinning plan given in Table 2.2.

The raw material was processed in the following technological chain of equipment of the modern firm "RIETER" (Switzerland). 
1. Automatic ball opener -Unifloc A11

2. Supply-mixing machine (pre-cleaner) Uniclean B11

3. Mixer -Unimix B70

4. Fine cleaner-Uniflex B60

5. Shaving machine $C 70$

6. Spinning machine SB-D-40 and RSB-D-40

7. Spinning machine R 40

The quality of the semi-finished product (yarn) and yarn was assessed by the following indicators:

- The degree of alignment and parallelism of the fibers in the cocoon and the fiber coil;

- Unevenness of the product by cut: linear and coefficient of variation;

- Unevenness on long shearing: $-1 \mathrm{~m}$ for cocoon, $-100 \mathrm{~m}$ for thread;

- Appearance defects of the thread: thin, thick areas, nodules (swelling);

- Unevenness in the relative tensile strength and relative tensile strength of the rope;

- Extension of the rope;

- Number of breaks in spinning machines.

Quality indicators of semi-finished products and yarn were determined by the standard method given in GOST [7, p. 625], as well as on modern measuring equipment USTER TESTER$5 \mathrm{M}$.

The degree of flattening and parallelization of the fibers was determined by an indirect method based on the determination of the work done in breaking the pile.

The quality of textile products largely depends on how smoothly the yarn is processed.

One of the main tasks of the research work is to improve the stretching equipment of spinning machines in the spinning process, reduce their unevenness by increasing the straightening and parallelism of fiber ends, reduce the number of yarn breaks in the production of quality textiles and knitwear, increase productivity, reduction, creating conditions for a positive impact on other economic indicators of the enterprise.

In order to eliminate the unevenness of individual cotton yarns and improve their quality, a new stretching device was created on the spinning machine ("Stretching device to increase the parallelism and flattening of fibers in the spinning machine" № FAP 013062018);

The quality of textile products depends mainly on the smoothness and cleanliness of the yarn and the methods of its preparation. Preparation of semi-finished products is one of the main ways to increase the efficiency of spinning mills, because the productivity of subsequent transitions depends on the unevenness of semi-finished products [6]. As a result of the use of a new stretching machine in a self-justifying spinning machine, we can produce high-quality yarn products, textile products that can compete in the world market, including suit fabrics of various compositions, and enter the world market under the Uzbek brand.

\section{CONCLUSION}

The experiment was carried out at the Peshkuteks farm on the improved cylinders of the RSB-D-40 spinning machine. In order to eliminate the unevenness of individual cotton yarns and improve their quality, a new stretching device was created in the spinning machine. The obtained yarn was produced on a G-35 spinning machine $\mathrm{Tt}=29,4$ textile, $\mathrm{Ta}=50$ textile, and its physical and mechanical performance was tested on a USTER TESTER$5 M[7$, p. 625]. The quality indicators of yarns and suit fabrics were determined on the basis of State Standards. Based on the results of the research, a quality yarn production technology was developed. 


\section{REFERENCES}

1. Decree of the President of the Republic of Uzbekistan No. PD-5285 "On measures to accelerate the development of the textile and knitwear industry." Tashkent. December 14, 2017.

2. Stretching tool of the spinning machine. Patent for utility model of the State Patent Office of the Republic of Uzbekistan. FAP 2014 0156. 2018.

3. Yang Jing, Xu Bojun Xie, Chunping Liu, Xinjin, Comparison of fibre migration in different yarn bodies/ Fibre end Textile Indian (IJFTR), Dec 2018.

4. Tyagi G. K., Bhowmick Manik, Bhattacharyya S., Kumar R., Effect of spinning conditions on mechanical and performance characteristics of cotton ring- and compact-spun yarns/ IJFTR Vol.35 (1) [March 2010]. - pp. 21-30.

5. Müller H., Maidel H. (1997) Abhdgigkeit der Rotorgarneigenschaften von der mechanischen Beanspruchung der Baumwolle beim Kardieren und Rotorspinnen/ Melliand Textilber. -78, №1,2. - p. 35.

6. Cyniak Danuta, Juzon Boguslaw. (1998) Investigation of the properties of yarn obtained on rotor spinning machines of different models. RS. Textile industry, No. 5. - p. 12.

7. Standards for testing yarns and fabrics. M., 1992-2012.

8. M.I. Bat and others. (1968) "Theoretical Mechanics", Nauka. - Moscow. - p. 625. 